\title{
Design Of An Improved Traditional African Granary: Literature Review
}

\author{
Kabinga Lawrence Kabuthi
}

\author{
Msc In Procurement And Logistics, 2013, JKUAT www.jkuat.ac.ke \\ Bsc In Purchasing And Supplies Management, 2011, JKUAT www.jkuat.ac.ke \\ Lawrence Kabinga is a Full Time Lecturer, The Kenya Institute Of Management In \\ Kenya, East Africa. www.kim.ac.ke
}

Email address; kabuthi.kabinga@gmail.com,

\section{lkabinga@lecturers.kim.ac.ke}

\begin{abstract}
In the past several decades, domineering influence from the western culture has played an important role in Africans abandoning their traditional foods for the more appearing western cuisines and highly refined factory foods. Unfortunately, this approach results in problems related to increase in lifestyle diseases such as diabetes, obesity, impotence in men, high blood pressure and cancer to name but a few. This problem has been largely studied and many viable solutions have been found including going back to consumption of traditional foods. Consequently, there has been much campaign and spirited debate in the media for the need to return to the consumption of African traditional foodstuffs to try to reduce the spread of the lifestyle diseases. On the same note, African communities have abandoned their traditional farming practices including food storage and warehousing practices. This turns out to be even more problematic because instead of improving their traditional food storage practices like granaries, on the contrary they have adopted urban systems, which have proved ineffective and inefficient. For instance, such poor storage practices include the following: the use of converted storage rooms in modern urban residential houses; construction of stock yards and sheds using cheap scientifically untested materials, poorly built traditional granaries due to loss of artisanship and knowledge from one generation to another and use of shopping bags and plastics. This is a basic chicken-and-egg problem, therefore, this article encourages the need for new research initiatives aimed at coming up with a newly designed African granary as a solution to reducing postharvest losses by rural farmers in Kenya and other developing countries. Other studies have failed to come up with a viable solution to the problems
\end{abstract}


occasioned by the traditional African granary and the modern versions in the markets. The aims of this research are twofold: firstly to find engineering solutions to the practical and applicability challenges facing the traditional African granary, secondly, to design a commercially viable technically practical traditional African granary prototype. Therefore, this paper evaluates the past and currents trends in the use of the African granary and proposes new technical improvements to make it more suitable in combating pest, rodents and disease invasion. This shall be done, by searching for appropriate literature on the current problems associated with the granary and forecasting the economic, technical, socio-cultural, governmental and legal benefits of a newly designed traditional African granary. This thesis will document several key contributions made to the fields of warehousing and stores management: to reduce post-harvest losses by $90 \%$ therefore combating food shortage and hunger in Kenya and other developing countries of the world.

\section{Key Words; Granary, Traditional African Granary, Concept Of Storage In Africa, History Of The African Granary, African Storage Systems, Concept Of Warehousing And Storage In African Traditional Societies,}

\subsection{Introduction}

Recent theoretical developments have revealed that, there has been spirited abandoning of traditional African practices and technologies in favor of western civilization alternatives since the conquest of Africa by the European settlers in the 1800 period. African civilizations neglected their tools, equipments and commercial practices in favor of new technologies brought about by the white settlers (Ezeanya-Esiobu, 2019). This seems to be a common problem in Africa and other developing countries. In this study, we are going to have a look at one such African tool and equipment that has faced near death extinction due to adoption of modernization concept (Iyegha, 2000). In other words, the traditional African granary was used to: preserve farm produce in large quantities in the rural areas, ensure food security, while the modern technologies have become a favorite product for the urban few. The African granary remains neglected because it has been replaced by the new technologies such as fridges, freezers and modern storage devices. The granary has faced a lot of competition from the modern technologies that fall short of the role- 
played by the African granary. There has been less previous evidence for how the new technologies have helped solve the problems facing rural farmers (ATIKU., 2013).

A well-known problem with modern grain storage structures is that they do not take into account the commercial and practical needs of their users. The key problem with these techniques is food insecurity due to post harvest challenges remains a thorny issue and there is a need to work on new research to bring back the African granary by modernizing the concept to improve its performance (Singh, 2017). A new approach is therefore needed, to support research to improve the African granary technically and technologically so that it can be promoted in the rural Africa as a way of preserving farm produce economically. The same trend has happened firstly, with the traditional African Jiko i.e. cooking stove that has been modernized to help the middle class and lower class in kenya and Africa at large, after the realization that we cannot replace traditional African tools and equipment with modern ones due to the issues of cost and applicability. Secondly, there has been efforts to promote scientific models and theories indegeneous to Africa such as the safari chain management theory (Kabinga, 2020) and The Ubuntu management system (Damane, 2001). Initial attempts to replace traditional cooking methods that have negative characteristics: rely on wood and charcoal fuels, are costly to use and pollute the environment, with cleaner-burning and more energy-efficient cook stoves have fallen short of expectations. Typically because the new stoves are only used for a short time, do not achieve the intended technical and economic objectives or they fail to fully displace the traditional methods. (Fiona Lambea, 2020). Therefore, after the engagement of scholars and professionals, scientists came up with a newly designed version of the traditional cooking stove that had more improved engineering parameters. Scientists spent considerable time in scientific laboratories testing the new design and the results were amazing.

\subsection{Background: Modernization Trends Of The African Cooking Stove: A Comparative Analysis}

Widely considered to be a good way to support the new phenomena is to look at what has happened in other related fields. In view of the above statement, we will start by analyzing concerning past research articles investigating the drivers for the need to design a new cooking stove and the then we shall look at the success rate of these initial strategies. In comparison, there are a few major similar characteristics between the traditional African granary and the Kenya traditional cooking 
stoves. I therefore analyzed drivers of the design of a newly improved Kenyan cooking stove and investigated whether the scholars behind this initiative succeeded in their ventures. It is clear that the problem associated with the traditional African granary could be easily tackled by benchmarking with the scientist approaches used to solve the problems previously associated with the Kenyan cooking stove (Fiona Lambea, 2020).

Firstly, we shall analyze data about the trend of household cooking stoves in Kenya by looking at how the traditional cooking stove is performing compared to the modern stove that is support to replace it. This is after the successful launch of the newly improved Kenyan cooking stove into the market. We shall look at if the traditional African stove is losing popularity or maintaining its popularity amongst the community. We shall look at the social value of the solid fuels and see if the more economical and environmentally friendly modern stoves have been able to change the behaviors of their users to embrace the new technology (AnthonyA.Bantu, 2018). We shall use this to determine if we should bring back the African granary to commercial use by improving its shortcomings. Unlike the traditional cooking stoves, the African granary has lost popularity and has been neglected, but the rural farmers have no alternatives. Researchers have attempted to replace the traditional cooking stove with modern cooking stoves which are more economical and health and environmentally friendly. The two products are a perfect substitute for each other if we ignore their social values of the households. On the other hand, it is impractical and unfeasible, to replace the traditional African granary with the modern fridges, freezers, semi-improved granaries or even modern warehouse due to cost and their applicability of the farmer's needs. Rural Kenyan farmers lack a convenient, safe, secure and reliable alternative to store their farm produce for a long period. Fridges, freezers and semi-improved traditional granaries are only a favorite to the urban households mainly for domestic use, whiles modern warehouse and storage facilities are too expensive to the ordinary rural famers. Let us discuss past literature in this area so that we can justify the need to bring back the African granary after a few technical, operational, design and concept adjustments to help the rural farmer store farm produce economically (Susanna B. Berkouwer, 2019).

Secondly, this research has been motivated by the current trends involving the modernization of the traditional African cooking charcoal stoves. (Traditional Kenyan Metallic Cooking Stoves 
(Kimani, 2020), Traditional Kenyan ceramic Cooking Stoves (Change, 2021), Modern Newly Improved Cooking Stoves (Burn, 2020).

In a study by Yuwan Malakar et all, (2018) titled "Resistance in rejecting solid fuels: Beyond availability and adoption in the structural dominations of cooking practices in rural India." The researcher found out that due to the social structures in India and other developing countries, the use of solid fuels as primary cooking fuels is going to continue for the next decades. This means the modern cooking methods such as kerosene, gas and electricity have failed to displace the traditional solid fuels therefore researchers should embrace the trend and carry out research to improve solid fuels usage while protecting the environment. (Panel Yuwan Malakar, 2018).

Solid fuels have a social value that is unique to each community therefore there total displacement is impossible. The social value of solid fuels varies from each individual in a community is measured by obtaining the economic value of the solid fuel minus any risks associated with the solid fuels. In the developing countries of the world, the social benefits of solid fuels outlays the risks hence their continued increase in usage for decades to come. A majority of the current renewable energy sources are too expensive and the services delivered from them have no value to their users hence the inability to replace the traditional solid fuels. Their socio technical designs adds no value to the end users in developing countries who associate them with non-value adding strategies that only increase cost with no beneficial aspects to them (Clark A. Miller, 2015).

Table 1.0: Research Papers Analyzed Concerning The Traditional Cooking Stove

\begin{tabular}{|l|l|l|l|}
\hline No & Country & Year & $\begin{array}{l}\text { No Of Research } \\
\text { Papers }\end{array}$ \\
\hline 1. & Uganda & 2018 & 2 \\
\hline 2. & Kenya & 2018,2020 & 7 \\
\hline 3. & Ghana & 2016 & 1 \\
\hline 4. & India & 2018 & 1 \\
\hline 5. & Guatemala & 2013 & 1 \\
\hline 6. & USA & 2015 & 1 \\
\hline & TOTAL & & $\mathbf{1 3}$ \\
\hline
\end{tabular}

(Source: Author 2021) 
Despite several changes in the market characteristics as well as technology characteristics, solid fuels have a large following. The clean cooking energy transitions is characterized by a large part of the population moving away from the solid fuels while at the same time we witness new entrants of people into the use of solid fuels as populations rise and economic and social conditions become tough (Abhishek Kar, 2018).

The use of solid fuels is a major health and environmental concern because it burns biomass to produce energy. Several stakeholders have launched initiatives aimed at replacing the traditional solid fuels cook stoves with modern ones by using strategies such as giving modern cook stoves for fee or even at a discount. However, the concerned household have not gotten rid of their traditional cook stove, but continue to use the two sets together. This concept is called cook stove stacking. The findings of the study indicate that the use of traditional cook stoves remained high despite their replacement initiatives because of community behaviors (Ricardo Piedrahita, 2016).

Another study was done in Guatemalan homes and reveled that half of the homes continued to use open fires that consumed solid fuels for cooking despite being given modern cook stoves to conserve the environment and avoid health concerns. This proved to be unsustainable in the end due to social concerns (Ilse Ruiz-Mercado, 2013). All the above literature indicate that it is not possible to replace and eliminate the traditional African cooking stoves because of social and behavior nature of the communities in the developing countries. Let us know look at literature concerning the African traditional granary and its current trend and position in the society.

\subsection{Literature Review: Traditional African Granary Trends In Africa}

According to a research paper by Mary W. Njonjo, et al, ( 2019). titled "Production Practices, Postharvest Handling, and Quality of Cowpea Seed Used by Farmers in Makueni and Taita Taveta Counties in Kenya." The number of rural households using the traditional African granary has reduced from $100 \%$ in the 1950 's to roughly $76 \%$ in wote region, $85.3 \%$ in makindu region and only $23.5 \%$ in mwatate regions of Kenya. This explain the situation in the lest of the country where 
the figures vary according to the level of urbanization and abandonment of culture. The areas which have abandoned the traditional African granary to high percentage witness greater loss of crop due to post harvest poor practices that lead to high crop loss. (Mary W. Njonjo, 2019).

Table 1.1: Statistics On The Use Of The African Granary By Rural Households In Kenya.

\begin{tabular}{|l|l|l|l|}
\hline Storage Place & Wote & Makindu & Mwatate \\
\hline House Racks & 24.0 & 14.7 & 74.5 \\
\hline Granary & 76.0 & 85.3 & 23.5 \\
\hline Kitchen & 0.0 & 0.0 & 2.0 \\
\hline
\end{tabular}

Source: Statistics On The Use Of The African Granary By Rural Households In Kenya, (Mary W. Njonjo, 2019).

Modern technologies used to preserve cereals after harvest have proven to be good on theory and scientific laboratories but impractical on the ground. Most of the farmers have difficulties using these new technology despite the high cost of acquisition. (Megan Sheahan, 2017). The main critic against the hermetic technologies is that it is based on controlled laboratory settings, not actual and often-imperfect use by farmers under their varied constraints and operating environments. These technologies concentrate on based on economic loss rather than the physical loss of farm produce lastly they fail to take into account the dynamics of supply chains. This implies that there still exist a gap when it comes to winning the war on post-harvest losses. This gap can only be filled by going back to the traditional African granary. This is the right time to do more research to improve on the African granary because it stands a better position on handling the pitfalls of modern storage systems. (Hippolyte Affognon, 2015).

There are two types of granaries that are commonly used among the savannah people of Nigeria and they are mainly made of cow dung but with slight variations among different ethnic tribes. These are the globular granaries and angular granaries. Granaries are widely used in a majority of the households and many of them are made of sword grass, stones, clay (mud) and cow dung. Most farmers rely on the grannies but due to the materials used to make, they incur a lot of post-harvest loses hence the need the improve them (Ogundele, 2010). Researchers are looking for environmentally friendly storage alternative to the use of chemicals and the current emphasize is the use of hermetic technologies which have proved to be unreliable (A. A. Chigoverah, 2018). The 
use of metal silos prevented damage by larger grain borer (LGB) and maize weevil for 98\% and $94 \%$ of adopters, respectively. This study finds evidence that metal silo technology is effective against main maize storage pests and its adoption can significantly improve food security in rural households. Distance to the nearest passable road reduced odds of adopting metal silo technology. (Zachary Gitonga, 2015). The same materials can be used to make the modern African granary as a strategy to reduce cereal spoilage.

Over the decades, the traditional African granary has equally evolved through various phases influenced by modernization, urbanization and desire to cut costs. However these new materials lack scientific basis and therefore, do not help tom combat post-harvest losses (Mhiko Tinotenda Admire, 2014). These phases are as indicated in the table below;

Table 1.2: Evolution Phases Of The African Granary.

\begin{tabular}{|l|l|l|}
\hline Phase & Type Of Granary & Construction Materials \\
\hline $\mathbf{1}$ & Traditional & Wooden pole and dagga walls \\
\hline $\mathbf{2}$ & Intermediate traditional & Poles, dagga platforms and bricks \\
\hline $\mathbf{3}$ & Intermediate improved & $\begin{array}{l}\text { Concrete platforms, brick and asbestos } \\
\text { roofs }\end{array}$ \\
\hline $\mathbf{4}$ & Improved & $\begin{array}{l}\text { Concrete platforms, bricks and thatched } \\
\text { roof }\end{array}$ \\
\hline
\end{tabular}

Source: Evolution Phases Of The African Granary, (Mhiko Tinotenda Admire, 2014)

According to the result, all assessed grain stores exhibited with significant infestation with storage insect pests. (Shiferaw, 2018). The results of the analysis demonstrate that granary buildings can maintain low temperatures and prevent moisture using eco-building techniques, such as ventilative stone ridges, moisture-resistant walls and heat insulation storage rooms (Yansong Wang, 2018). The result of the findings shows that the common grain storage structures existing in the zones are the mud rhombus, thatched rhombus, underground pit, platforms, earthen pots, cribs respectively. The grain usually stored in un-threshed forms includes millet, sorghum, maize and cowpea. Most of these structures are not moisture proof, rodent proof and are not airtight. Structural defects occur mainly in the roof, walls and columns of the storage structures. The common types of physical defect are cracks, leakage, termite infestation and structural failure of parts. The causes of defects 
among others include poor strength of materials, inadequate columns, low elevation and pest infestation (ATIKU., 2013).

Traditionally farmers in rural areas in some parts of India and Africa use traditional granaries to store their grains (Figure 4). The granaries are found not to be very effective against storage pests. Hence, a need for suitable storage facilities and management technologies following the cultural control methods. This lack somehow forces farmers to sell their grain immediately after harvest. As a result, farmers receive low market prices for any surplus grain they may produce due to storage weevil damage (Maletsema Alina, 2016). Farm storage structures should provide maximum protection against deterioration caused by rain and ground moisture, provide a barrier to pest attack and deter theft. Traditional farm storage systems have evolved over long periods to satisfy these requirements. Most are well adapted to their environment and losses are generally low, often below 5\% of grain weight over a storage season. Higher losses may occur if the equilibrium of the traditional post-harvest system is disrupted (Robin Boxall, 2019).

Farmers in Sub-Saharan Africa use storage structures that help maintain grain quality and safety. This study reviewed the use of different grain storage structures used by smallholder farmers in Zimbabwe namely granaries, metal silos, super grain bags, polypropylene bags and cribs. Metal silos and super grain bags, however costly, have hermetic properties that kill pests while granaries dilapidate with time. Cribs are susceptible to moisture entry, while polypropylene bags are prone to perforations by sharp objects (Rudo Florence Mapfeka, 2019). The successful functioning of a granary, i. e. the storage of life-sustaining contents, is truly vital, and its structural failure forebodes the doom of the family unit. As in other art forms where usage is a scritical factor, there is little room for mediocrity in structural design or its execution13. The range of formal variation is more limited than in other art forms, yet it is precisely this limitation, which in turn becomes a challenge for the West African builder (Prussin, 1972).

Thus, the main objective of this thesis was to develop and test an improved hermetic grain storage system for the smallholder farmers in Tanzania that can effectively store maize grain without addition of any chemicals. The proposed storage system was fabricated using locally available materials in Tanzania. The improved storage structure was tested by comparison with the conventional system using polyethylene sacks for six months using maize grains. The results suggest that the improved hermetic grain storage system stored grain better than polyethylene 
sacks used in the conventional system. The improved storage system shows the potentials to prolong maize storage period and ensure food security by reducing post-harvest food losses (Milindi, 2016). Storage is particularly important in Africa because agricultural production is mostly seasonal while the demand for agricultural commodities is more evenly spread throughout the year. The storage methods identified include the use of rhombus, traditional cribs, underground pits, open stack storage, woven baskets, grain silos, farm store, communal warehouses and domestic storage techniques. Most of the storage methods experience the problem of insect infestation though at varying level depending on the structure. The use of metal silo is the most effective method of storing grains in Africa, with very high utilization rate in South Africa and spreads across the continent. Despite this fact, it still has the lowest adoption level in Africa as a continent (Nwaigwe, 2019).

Local artisans and craftsmen in the informal sector have tried to modernize the traditional African granary by adopting new building materials. They have copied their architectural design from the well-established grain silos mainly built by the governments and private companies and tried to make it portable and affordable to the rural farmers. This has been done by use of readily available materials such as corrugated and smooth walled steel, aluminum and plastics. A major observation is the overemphasized hermetic properties of the silo: the ability to look out air killing all pests and rodents ignoring other crucial engineering aspects (BARIGABA, 2016).

Although farmers have tried to modernize the traditional African granary, their efforts have born little success. Firstly, the structures they have tried to construct are technically and practically unrealistic due to lack of scientific research. Secondly, the fourth generation metallic silos made from aluminum and steel sheets have proven unreliable. They allow massive loss of stored grain through pest and aflatoxin infestation, variation of temperatures, stored grain forms masses assuming a thick hard solid state due to amassing of vapor inside the silo wall (Joash Bwambale, Development and evaluation of an improved maize silo to advance food security in Uganda, 2020). On the other hand, plastic containers allow for an increase in accumulation of moisture at pick of the storage container over time resulting to aflatoxin infestation (Shlomo Navarro, 1985). 


\subsection{Objectives Reinforcing Investments In A Newly Improved Traditional African Granary}

A majority of the current cereal and farm produce storing ways and means experience the challenge of pest and rodent influx while there is low adoption rate of modern alternatives due to cost factors (Nwaigwe, 2019). On the other hand, lack of appropriate storage facilities for harvested farm produce encouraged farmers to sell away their produce immediately after harvesting at a lower price compared to cost of buying food afterwards (Zachary Gitonga, 2015). Furthermore, resent studies indicate that, global warming and other changes in the environment caused by pollution of the ecosystem is forecasted to alter and change insect pest behavior process through mutation over and above growing mould infection of stored grains thereby increasing post-harvest losses and hunger in Africa and other developing countries (Rudo Florence Mapfeka, 2019). Metal silos and supergrain bags, remain common for their usefulness in conserving grain class but are very costly and out of reach of ordinary rural farmers. Traditional granaries and cribs depreciate over prolonged use encouraging wetness and grain decomposition, while polypropylene bags are vulnerable to punctures that cause reduced grain quality (Rudo Florence Mapfeka, 2019).

Despite various recommendations from past researches by scholars on practices to reduce postharvest losses, their rate of adoption has been low. This is due to unavailability of financial and technical resources, unsuitability of the methods and inopportune practices (Robin Boxall, 2019). A majority of the current challenges posed by the traditional African granary emanate from its architectural design. The architectural design of most granary borrows heavily from the architectural designs for domestic houses. This means that, the structural and architectural designs is technically not suited for grain and farm produce preservation thus increasing post-harvest losses (Yansong Wang, 2018). The traditional African granary is heavily prone to attack by weevils that cause grain loss and damage to the tune of $77 \%$ causing hunger and starvation (Maletsema Alina, 2016). To add salt to the injury, there has been increased incidences of imported grains pest from other continents finding their way in African. These indigenous pests enter the continent through imported maize, rice and wheat and they have increased post-harvest losses over the decades (Mhiko Tinotenda Admire, 2014). 


\subsection{Expected Benefits Of A Newly Improved Traditional African Granary}

Primarily, a newly improved traditional African granary is expected to increase stored grain quality and increase cereals market value (Alhaji Mohamed Hamza Conteh, 2015). Secondly, the fourth generation metallic silos made from aluminum and steel sheets have proven unreliable. They allow massive loss of stored grain through pest and aflatoxin infestation, variation of temperatures, stored grain forms masses assuming a thick hard solid state due to amassing of vapor inside the silo wall. Therefore, a newly designed and improved structure will help to curb these problems. (Joash Bwambale, Development and evaluation of an improved maize silo to advance food security in Uganda, 2020). Thirdly, farmers won't have to sell their farm produce earlier to avoid loss on the farm, but will be able to keep the stored grain for longer periods of time enabling them to avoid hunger and they will be able to sell the surplus at a much higher profit (Evelyne Gbénou-Sissinto, 2018). It is obvious knowledge that adoption of enhanced storing arrangements causes such profits as postharvest losses decline, product quality safeguarding and greater than before length of storage (Charles Owach, 2016).

\subsection{Scope Of The Study}

There are growing appeals for scholars to carry out research aimed at reducing post-harvest losses

witnessed by rural farmers due to the use of the traditional storage methods. Therefore, this study is limited to the supply chain management discipline and warehousing and storage sub discipline. The focus is post-harvest storage practices practiced by rural farmers in Kenya and other developing countries. To illuminate this uncharted area, we shall examine the following postharvest storage practices: harvesting, drying, threshing, shelling, winnow, cleaning, receiving of farm produce after harvesting, sorting, grading and cleaning of harvested farm produce, fumigation against pest and rodents invasion, fumigation against common disease infection, storage of farm produce in protective polythene bags, sacks and even gunny bags, granary security and safety and lastly movement (loading and offloading) of stored farm produce. Despite the neglect of the African granary due to urbanization and adoption of modern practices, the traditional African granary remains a crucial element of the food supply chain and food value chain in Kenya and other developing countries (Kabinga, 2016). 


\subsection{Materials And Methods}

\subsection{Selection Of Study Area}

Primary data will be collected from agricultural engineering experts on the qualities of a good newly improved traditional African granary. The researcher will contacts various companies, nongovernmental organizations and government agencies involved in the research, development and commercialization of the Kenyan Ceramic Jiko (KCJ). These stakeholders have in the past been involved in the creation of the new improved traditional African charcoal cooking stove, and their experience, knowledge gained and current technical capacity will be a valuable input for the design of the newly improved traditional African granary. These are the stakeholders who will be engaged in the developed of the new designs for the newly improved traditional African granary. These organizations will include the following: 
Table 1.4: Data Collection Organizations

\begin{tabular}{|c|c|c|}
\hline Name & Organization Website & Phone Number And Email Address \\
\hline $\begin{array}{l}\text { Burn Design Lab } \\
\text { And BURN } \\
\text { Manufacturing } \\
\text { Co }\end{array}$ & $\underline{\text { https://burnstoves.com/ }}$ & $\begin{array}{l}+254706585629 \\
\text { kenya@burnmfg.com }\end{array}$ \\
\hline $\begin{array}{l}\text { Kenya Climate } \\
\text { Innovations } \\
\text { Center }\end{array}$ & $\begin{array}{l}\text { https://www.kenyacic.org/2017/03/15/transforming- } \\
\text { lives-through-improved-cook-stoves/ }\end{array}$ & Tel: +254 703034 701/03 Email: info@kenyacic.org \\
\hline Cookswell Jikos & $\begin{array}{l}\text { https://cookswell.co.ke/product/kuni-saver-firewood- } \\
\text { jiko/ }\end{array}$ & $0725800251 \quad \underline{\text { info@,cookswell.co.ke }}$ \\
\hline $\begin{array}{l}\text { Bio Energy Lists } \\
\text { Organization }\end{array}$ & $\begin{array}{l}\text { http://stoves.bioenergylists.org/content/research- } \\
\text { development-and-commercialization-kenya-ceramic- } \\
\text { jiko-and-other-improved-biomass-sto }\end{array}$ & list@sylva.icuklive.co.uk tmiles@trmiles.com \\
\hline $\begin{array}{l}\text { Infonet } \\
\text { Biodivision }\end{array}$ & $\begin{array}{l}\text { https://infonet- } \\
\text { biovision.org/EnvironmentalHealth/Energy-Saving- } \\
\underline{\text { Cookstoves }}\end{array}$ & $\begin{array}{l}+254719052195,+254715422460 \\
\text { m.hunziker@biovision.ch } \\
\underline{\text { hshiraku@,biovisionafrica.org }}\end{array}$ \\
\hline Ecozoom & $\begin{array}{l}\text { https://ecozoom.com/blogs/ecozoom/introducing-the- } \\
\text { jiko-bora-mama-yao-the-most-efficient-charcoal- } \\
\text { cookstove-in-kenya }\end{array}$ & $\begin{array}{l}+(254) 792323392 \\
\text { support@bioliteenergy.com }\end{array}$ \\
\hline Scode Ltd Kenya & https://enterprise.scode.co.ke/ & $\begin{array}{l}+254723767265 \\
\text { scodeltd@scode.co.ke } \\
\end{array}$ \\
\hline $\begin{array}{l}\text { Envirofit Ltd } \\
\text { Kenya }\end{array}$ & https://envirofit.org/ & $\begin{array}{l}+245(0) 800722700 \\
\text { eastafrica-sales@,envirofit.org } \\
\text { customercarekenya@envirofit.org }\end{array}$ \\
\hline $\begin{array}{l}\text { Clean Cooking } \\
\text { Aloliance }\end{array}$ & https://www.cleancookingalliance.org/home/index.html & $\begin{array}{l}\text { info@,cleancookingalliance.org } \\
202.887 .9040\end{array}$ \\
\hline
\end{tabular}

Source: Data Collection Organizations, (Author 2021) 


\subsection{Requirements Of A Good Newly Designed Traditional African Granary;}

\subsubsection{Technical And Laboratory Analysis}

Scientific research has managed to design new improved storage structures that are hermetic (able to lock out entry of air thus killing pests), rodents proof and waterproof. These studies have failed to solve the major challenge facing rural farmers, which is the accumulation of moist and consequently the formation of aflatoxin mould (moist forms inside the metallic structures once there is a difference in temperature between the inside and outside of the structure) (Mhiko Tinotenda Admire, 2014). To overcome this problem, in the next section we demonstrate the need to develop alternative granary storage material that solve this problem. The other major challenge is rust, because most of the current structures are made of readily available materials that rust quickly when placed outdoors (A. A. Chigoverah, 2018). There is need to develop a new material that can be comfortably placed outdoors during rainy seasons without rusting. This strategy is not uncommon in this kind of problems.

\subsubsection{Economic Analysis}

For the newly improved African granary to be effective, it must be economically affordable to the rural farmers and also prove that it adds economic benefit to the rural farmers. Rural farmers are price sensitive because of their financials capacity, therefore they will not invest their hard earned cash on a project that is not justifiable to them. To take care of this, the researcher suggests the use of the net present value (NPV), internal rate of return (IRR) and benefit cost ratio approaches to determine the economic analysis of agricultural technologies. Here we solve several problems simultaneously.

In general, this problem can be tackled in two different ways. Firstly, the NPV is used to calculate the present worth of the income stream generated by an investment to the farmer, in this case the newly improved traditional African granary. Secondly, the IRR is used to calculate the maximum interest amount the farmer will have to pay for newly improved traditional African granary until they get the actual money invested back ( breakeven). And finally, the BC ratio is used to calculate the current value of the financial benefits delivered from the use the newly improved African traditional granary compared with cost of acquisition of the entire agricultural technology. While using the above methods, we make use of 10 years as the investment period. This methodology 
was borrowed from another study titled "Effective Grain Storage for Better Livelihoods of African Farmers Project” by Maria Luz C. George (George, 2011).

\subsubsection{Government And Regulatory Analysis}

Unfortunately, this approach results in problems related to post-harvest losses, food security, hunger and starvation is a common problem facing government in Kenya and other developing countries. This is part of the United Nations millennium development goals and all governments are looking for scientific solutions to solve this problem ponce and for all. A number of works have shown that this problem can be overcome by bringing onboard governments in developing countries to help in the design and development of the newly improved traditional African granary. They can help by coming up with subsidies and tax relieves to help the various stakeholders helping farmers acquire these agricultural technologies. can also help by proving infrastructural accessibility of their research and scientific centers to be used for design and pilot testing of the proto types.

\subsection{Practical Analysis}

Recent methods focus on overcoming the problems by proposing different schemes for effective and efficient grain storage solutions for the farmers, it should be readily available in the market and finally it should be portable for ease of placing indoors and outdoors and for ease movement from one point to another ( (Joash Bwambale, 2020). All of these advantages make it particularly valuable in making the newly improved traditional African granary a favorite with the rural farmers in Kenya and other developing countries.

\subsection{Methods Of Data Collection}

This research will be based on the systematic new product development methodology proposed by M. Salhieh and Sa'Ed, (2018) titled "A systematic new product development methodology for creating affective products". The methodology incorporates the procedures desirable to provoke together tangible/objective and intangible/affective consumer wants and converts those wants into product restrictions to be used in the development of new products that meet both the customer functional and affective needs. Firstly, the approach starts by recognizing consumer touchable and 
untouchable needs, and then transforms those needs into measurable values. Secondly, visual representation is done to determine where the brand attitudes in the midst of rivals. This is trailed by defining of the preliminary design and selection of a fresh locus for the new product in the marketplace. Lastly, new product concepts will be created and verified (Salhieh, 2018). In view of the above, to ensure the success of this method, we are going to use the below table to measure the viability of the newly improved traditional African granary process (Bhuiyan, 2011).

Table 1.3: Critical Success Factors and Metrics for Stages of NPD Process

\begin{tabular}{|l|l|}
\hline Stage & Tools And Techniques \\
\hline New product strategy. & $\begin{array}{l}\text { Financial analysis. } \\
\text { Balanced-scorecard. }\end{array}$ \\
\hline Idea generation. & $\begin{array}{l}\text { Lead User Methodology. } \\
\text { Ethnographic Approach. }\end{array}$ \\
\hline Screening and business case. & Financial Method of evaluation. \\
\hline Development. & $\begin{array}{l}\text { Team Cohesiveness. } \\
\text { Dynamic Time to Market. } \\
\text { Degree of Parallelism. }\end{array}$ \\
\hline Testing. & Validation Testing. \\
& User and Field Testing \\
\hline
\end{tabular}

Source: Critical Success Factors And Metrics For Stages Of NPD Process, (Bhuiyan, 2011) 


\section{BIBLIOGRAPHY}

A. A. Chigoverah, B. M. (2018). Are GrainPro Cocoons ${ }^{\mathrm{TM}}$ an efective alternative to conventional phosphine fumigation in large-scale control of stored-maize insect pests? Journal of Pest Science, 91, 1393-1406. doi:DOI 10.1007/s10340-018-0996-7

Abhishek Kar, H. Z. (2018, March 9). From cookstove acquisition to cooking transition: Framing the behavioural aspects of cookstove interventions. Energy Research \& Social Science, 42, 23-33. doi:https://doi.org/10.1016/j.erss.2018.02.015

Africa, F. (2020). Profit Boosters. Retrieved from FarmBiz Africa: https://farmbizafrica.com/profit-boosters/1828-unique-silos-insulate-farmers-fromweevil-attacks

Alamy. (2016, December 5). Traditional, tribal granary of Kenyan people, Nairobi, East Africa. Retrieved from Alamy Ltd: https://www.alamy.com/stock-photo-traditional-tribalgranary-of-kenyan-people-nairobi-east-africa-147638665.html

Alhaji Mohamed Hamza Conteh, X. Y. (2015). The determinants of grain storage technology adoption in Sierra Leone. Cah Agric, 24(1). doi:10.1684/agr.2015.0733

AnthonyA.Bantu, G. S. (2018). Design of an Improved Cooking Stove Using High Density Heated Rocks and Heat Retaining Techniques. Journal of Renewable Energy. doi:https://doi.org/10.1155/2018/9620103

Ashish Manandhar, P. M. (2018). An Overview of the Post-Harvest Grain Storage Practices of Smallholder Farmers in Developing Countries. Agriculture, 8(57). doi:10.3390/agriculture 8040057

ATIKU., M. A. (2013). ASSESSMENT OF SOME TRADITIONAL GRAIN STORAGE STRUCTURES IN MUBI SENATORIAL ZONE OF ADAMAWA STATE. Education and Science Journal of Policy Review and Curriculum Development, 3(3). Retrieved October 28, 2020, from https://www.scribd.com/document/390756060/Article-5Assesment-of-Stone

BARIGABA, J. (2016, June 9). Better grain storage methods can end post-harvest losses. Retrieved from The East African: https://www.theeastafrican.co.ke/tea/sciencehealth/better-grain-storage-methods-can-end-post-harvest-losses--1350992

Bhuiyan, N. (2011). A framework for successful new product development. Journal of Industrial Engineering and Management, 4(4), 746-770. doi:http://dx.doi.org/10.3926/jiem.334

Burn, D. L. (2020). The Future of Clean Cooking. Retrieved from Burn life saving stoves: https://burnstoves.com/

Change, E. F. (2021). kenyan-domestic-ceramic-jiko-stove. Retrieved from Engineering for cvhange: https://www.engineeringforchange.org/solutions/product/kenyan-domesticceramic-jiko-stove/ 
Charles Owach, G. B. (2016). Factors influencing the use of food storage structures by agrarian communities in Northern Uganda. Journal of Agriculture, Food Systems, and Community Development, 7(2), 127-144. doi:https://doi.org/10.5304/jafscd.2017.072.003

Clark A. Miller, C. A.-A. (2015, January 17). The social value of mid-scale energy in Africa: Redefining value and redesigning energy to reduce poverty. Energy Research \& Social Science, 5, 67-69. doi:https://doi.org/10.1016/j.erss.2014.12.013

Culture, A. g. (2011). INDIGENOUS METHOD OF FOOD AND SEED SAVING KAPCHELONGE VILLAGE, KENYA. Retrieved from A growing Culture: http://agrowingculture.org/indigenous-method-of-food-and-seed-saving-kapchelongevillage-

kenya/\#: :text=In\%20the\%20remote\%20lowlands\%20of,choge\%E2\%80\%9D\%20in\%20 the $\% 20$ local $\% 20$ language.

Damane, M. P. (2001). Building Competitive Advantage from "Ubuntu": Management Lessons from South Africa [and Executive Commentary]. The Academy of Management Executive (1993-2005), 15(3). Retrieved from https://www.jstor.org/stable/4165756?seq=1\#metadata_info_tab_contents

Evelyne Gbénou-Sissinto, Y. P. (2018). Farmers' Willingness to Pay for New Storage Technologies for Maize in Northern and Central Benin. Sustainable Agriculture, 10(8). doi:https://doi.org/10.3390/su10082925

Ezeanya-Esiobu, C. (2019). Africa's Indigenous Knowledge: From Education to Practice. Indigenous Knowledge and Education in Africa, 55-80. doi:https://doi.org/10.1007/978981-13-6635-2_5

Fiona Lambea, ,. Y. (2020, August 19). Opening the black pot: A service design-driven approach to understanding the use of cleaner cookstoves in peri-urban Kenya. Energy Research And Social Science, 70, 2214-6296. doi:https://doi.org/10.1016/j.erss.2020.101754

George, M. L. (2011). Effective Grain Storage for Better Livelihoods of African Farmers Project . Mexico: International Maize and Wheat Improvement Center .

Hippolyte Affognon, C. M. (2015). Unpacking Postharvest Losses in Sub-Saharan Africa: A Meta-Analysis. World Development, 66, 49-68. doi:https://doi.org/10.1016/j.worlddev.2014.08.002

Ilse Ruiz-Mercado, E. C. (2013, August 2). Quantitative metrics of stove adoption using Stove Use Monitors (SUMs). Biomass and Bioenergy, 57, 136-148. doi:https://doi.org/10.1016/j.biombioe.2013.07.002

Iyegha, D. A. (2000). THE WISDOM OF TRADITIONAL FARMING IN TROPICAL AFRICA: THE NIGERIAN EXPERIENCE. Journal of third world studies, 17(2), 73-92. Retrieved March 2, 2021, from https://www.jstor.org/stable/45198194?seq=1\#metadata_info_tab_contents 
Joash Bwambale, O. S. (2020). Development and evaluation of an improved maize silo to advance food security in Uganda. Cogent Food And Agriculture, 6(1). doi:10.1080/23311932.2020.1834666

Joash Bwambale, O. S. (2020). Development and evaluation of an improved maize silo to advance food security in Uganda. Cogent Food And Agriculture, 6(1), 1-16. doi:10.1080/23311932.2020.1834666

Kabinga, L. K. (2016). Warehouse and Supply Chain Management: Concept, History and Trends. Kindle Direct Publishing, Amazon Online . Retrieved October 22, 2020, from https://www.amazon.com/gp/product/B01AAFEUQE/ref=dbs_a_def_rwt_hsch_vapi_tki n_p1_i4

Kabinga, L. K. (2020). Safari Chain Management Theory. A "New" Theory Of Supply Chain Management. ssrn, 24. doi:http://dx.doi.org/10.2139/ssrn.3719972

Kimani, M. N. (2020). Energy Saving Cookstoves. Retrieved from Infonet Biovision: https://infonet-biovision.org/EnvironmentalHealth/Energy-Saving-Cookstoves

Maletsema Alina, M. (2016). Control strategies and breeding efforts in sorghum for resistance to storage weevils. African Journal of Agricultural Research, 11(33), 3065-3073. doi:10.5897/AJAR2016.11164

Mary W. Njonjo, J. W. (2019). Production Practices, Postharvest Handling, and Quality of Cowpea Seed Used by Farmers in Makueni and Taita Taveta Counties in Kenya. International Journal of Agronomy, 12. doi: https://doi.org/10.1155/2019/1607535

Megan Sheahan, ,. C. (2017). Review: Food loss and waste in Sub-Saharan Africa. Food Policy, 70, 1-12. doi:https://doi.org/10.1016/j.foodpol.2017.03.012

Mhiko Tinotenda Admire, S. T. (2014). Efficacy of Traditional and Improved Granaries in Protecting Maize from Prostephanus truncatus in Small Holder Farming Storage System in Makonde District, Zimbabwe. World Journal of Agricultural Research, 2(2), 63-69. doi:DOI:10.12691/wjar-2-2-6

Milindi, P. (2016). Improved Hermetic Grain Storage System for Smallholder Farmers in Tanzania. Retrieved from https://core.ac.uk/display/83050519

newspaper, t. e. (2020, october 1). The granary is a weapon against food scarcity in uncertain times. Retrieved from the east african newspaper:

https://www.theeastafrican.co.ke/tea/oped/comment/the-granary-weapon-against-foodscarcity-in-uncertain-times-2454752

Nwaigwe, K. N. (2019). An Overview of Cereal Grain Storage Techniques and Prospects in Africa. International Journal of Bioengineering \& Biotechnology, 4(2), 19-25.

Ogundele, S. O. (2010). Ethnography of Granary Architecture and Identities of Two Savanna People of Nigeria. Department of Archaeology and Anthropology. Retrieved October 28, 
2020, from

http://citeseerx.ist.psu.edu/viewdoc/download?doi=10.1.1.507.6823\&rep=rep1\&type=pdf

Panel Yuwan Malakar, C. G. (2018, December 1). Resistance in rejecting solid fuels: Beyond availability and adoption in the structural dominations of cooking practices in rural India. Energy Research \& Social Science, 46, 225-235. doi:https://doi.org/10.1016/j.erss.2018.07.025

Prussin, L. (1972). West African Mud Granaries. Paideuma. Retrieved from https://www.jstor.org/stable/40341525?seq=1\#metadata_info_tab_contents

Ricardo Piedrahita, K. L. (2016, October). Assessment of cookstove stacking in Northern Ghana using surveys and stove use monitors. Energy for Sustainable Development, 34, 67-76. doi:https://doi.org/10.1016/j.esd.2016.07.007

Robin Boxall, P. G. (2019). Pest Management In Farm Granaries With Special Reference To Africa. Natural Resources Institute. Retrieved from https:/gala.gre.ac.uk/id/eprint/10764/

Rudo Florence Mapfeka, R. M.-M. (2019). Post-harvest cereal structures and climate change resilience in rural Zimbabwe: a review. International Journal Of Postharvest Technology and Innovation, 6(4). doi:https://doi.org/10.1504/IJPTI.2019.106460

Salhieh, S. M. (2018). A systematic new product development methodology for creating affective products. International Journal of Engineering \& Technology, 7(4), 4743-4752. doi:10.14419/ijet. v7i4.19617

Shiferaw, T. (2018, January 9). Occurrence of Stored Grain Insect Pests in Traditional Underground Pit Grain Storages of Eastern Ethiopia. Journal of Biology, Agriculture and Healthcare. doi:10.19080/ARTOAJ.2018.13.555879

Shlomo Navarro, E. D. (1985). PLASTIC STRUCTURES FOR TEMPORARY STORAGE OF GRAIN. THE EIGHTH ASEAN TECHNICAL SEMINAR ON GRAIN POST-HARVEST. TECHNOLOGY (pp. 1-6). Manilla, Philippenes: R.L., Semple and A.S. Frio.

Singh, R. S. (2017). Traditional agriculture: a climate-smart approach for sustainable food production. Energy, Ecology and Environment, 2, 296-316. doi:https://doi.org/10.1007/s40974-017-0074-7

Susanna B. Berkouwer, J. T. (2019). Credit and attention in the adoption of profitable energy efficient technologies in Kenya. Job Market Paper. Retrieved from http://www.susannaberkouwer.com/files/theme/BerkouwerJMP.pdf

Yansong Wang, Y. Y. (2018). A Study of the Forms and Technology of Traditional Granary Buildings in the Middle and Lower Reaches of the Fu River. Journal of Asian Architecture and Building Engineering. doi:https://doi.org/10.3130/jaabe.17.175

Zachary Gitonga, H. D. (2015, May 12). Metal silo grain storage technology and household food security in Kenya. Journal of Development and Agricultural Economics, 7(6), 222-230. doi:10.5897/JDAE2015.0648 
